\title{
Book review: International reflections on Realistic Mathematics Education
}

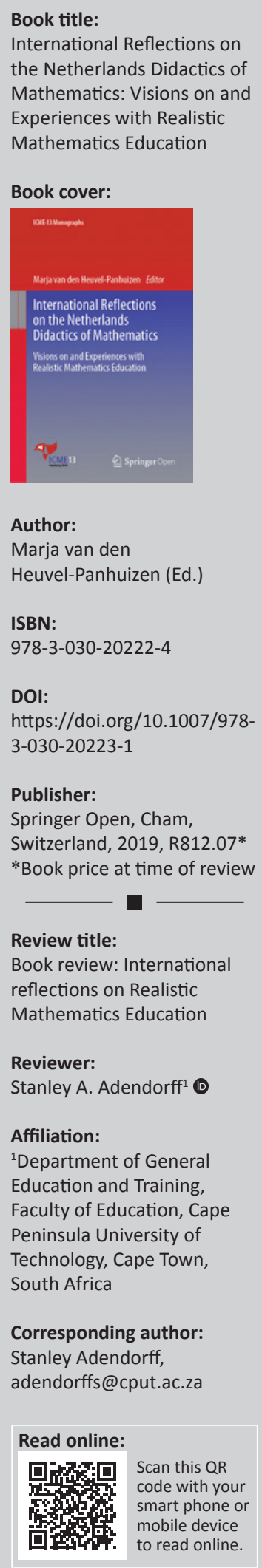

Author:

Marja van den

Heuvel-Panhuizen (Ed.)

ISBN:

978-3-030-20222-4

DOI:

https://doi.org/10.1007/978-

3-030-20223-1

Publisher:

Springer Open, Cham,

Switzerland, 2019, R812.07*

*Book price at time of review

$\square$

Review title:

Book review: International

reflections on Realistic

Mathematics Education

Reviewer:

Stanley A. Adendorff ${ }^{1}$ (D)

\section{Affiliation:}

${ }^{1}$ Department of General

Education and Training,

Faculty of Education, Cape

Peninsula University of

Technology, Cape Town,

South Africa

Corresponding author:

Stanley Adendorff,

adendorffs@cput.ac.za

\section{Read online:}

Read online:
Scan this QR
code with your
smart phone or
mobile device
to read online.

\section{Introduction}

Initially I was reluctant to accept what I considered to be the daunting task of reviewing this academic text which exclusively shares encounters that deal with manifold authentic incidents of grappling with Realistic Mathematics Education (RME) on a global scale. I still wonder why I said 'yes' eventually.

My first exposure to Realistic Mathematics Education started when I was working on the Realistic Mathematics Education in South Africa (REMESA) project (see chapter 5) under Cyril Julie (University of the Western Cape) and Heleen Verhage (Freudenthal Institute, University of Utrecht) at the turn of the century and later on with Bertus van Etten of Fontys Hogenscholen, University of Fontys, on the Brave Maths Project at Stellenbosch University, South Africa. That was the time when I 'made acquaintance with RME' (Van den Heuvel-Panhuizen, p. 2) and in a sense became 'part of the Dutch RME community' (Van den Heuvel-Panhuizen, p. 1). Having been exposed to the principles underlying RME also gave me 'a new perspective on understanding mathematics education' (Van den Heuvel-Panhuizen, p. 3), similar to the experiences of some of the contributing authors. The purpose of this review, however, is not to share what I understand RME to be, but rather to make sense of, and express some impressions of the value of, this particular book in terms of the advancement of RME globally.

\section{The thesis of the book}

What is the central issue the book addresses? Well, the title says it all. The title of the book is focused and unambiguous: International reflections on the Netherlands didactics of mathematics: Visions on and experiences with Realistic Mathematics Education. These visions and experiences already come to life in the editor's chapter 1 . The global use and application of RME, and the unique and diverse experiences in various international communities, are clearly evident from this text. The editor's chapter 1 is well written and summarises the overview of the salient aspects quite impressively. It consequently makes me wonder why an additional review of the book was sought. The section titled 'Making acquaintance with RME' is compelling and absorbing and captures the global essence of RME. The way the book is organised seems to support this thesis. The chapters seem to be randomly ordered with particular aligned themes evident. The different points of departure of the authors are contained in keywords that appear in the titles of the chapters: in chapter 2 the emphasis is on 'application' of RME; chapters 3, 4, 12, 16 and 17 critically deal with the 'influence' and 'impact' thereof; chapter 5 and 10 share 'reflections' of particular experiences with RME; chapter 6 pays 'tribute' to RME; chapter 18 gives a historical perspective over 'two decades' of adapting RME to a particular context; chapter 19 discusses how RME is used in an 'intervening' sense in a particular context.

Apart from critically analysing the title initially, the attention intuitively shifts to who the contributing authors are. In this book you need to read the chapter first to get some idea of the authors in terms of credibility and qualifications. Some brief personal information, and in addition a website link where more related information about the authors may be found, would be beneficial. This book, I believe, was not necessarily written with profit-making in mind, but mentioning the established reputation of contributing authors could be compelling in terms of purchasing a copy of the book. Names - in no particular order - such as Van den HeuvelPanhuizen, Janssens, Julie, Gierdien, Niss and Zulkardi are more familiar to me, but brief

How to cite this book review: Adendorff, S.A. (2019). Book review: International reflections on Realistic Mathematics Education. Pythagoras, 40(1), a525. https://doi.org/10.4102/pythagoras.v40i1.525

Copyright: @ 2019. The Authors. Licensee: AOSIS. This work is licensed under the Creative Commons Attribution License. 
biographical information of the authors is needed to orientate myself as reader. As far as could be ascertained each chapter states the author's place of work and gives a brief indication of who the authors are, together with their email addresses.

There are some definite universal experiences related to RME that are common to all the different experiences and scenarios as captured by the different authors. At the same time the unique encounters the authors experienced when introducing, sharing and training educators in terms of RME are also evident. In addition to providing a global perspective, RME is dissected meticulously, to reveal its dynamic and intricate nature. Having gained insight into the crux of each of the chapters has made me realise that RME is an all-encompassing theory of teaching and learning mathematics: it includes and applies the ideas of Vygotsky's social constructivism, Skemp's (1978) ideas related to relational versus instrumental teaching and learning of mathematics, the Van Hiele levels of geometry learning, Sfard's (2015) theory of commognition, of dealing with cognition and communication when learning and teaching mathematics, to name but a few.

The search for didactical strategies other than those involving drilling and algorithmic procedures (Arcavi, p. 83) compelled educationists to explore the merits of adopting and working with RME principles. This resulted in what De Bock, Van Dooren and Verschaffel in chapter 3 (p. 53) call 'RME inspired changes'. They noticed in terms of the different mathematical domains that in numbers and operations, the attention shifted from obtaining insight in the structure of number systems to linking numbers to quantities'. As a result, 'numbers are no longer purely abstract entities, but objects that children learn to know and recognise in different forms.' In addition, 'with respect to operations, the emphasis shifted from discovering and accurately formulating the commutative, associative and distributive laws to linking operations to concrete and meaningful situations'. These are just some of positive outcomes reported that are RME inspired.

\section{Critique of Realistic Mathematics Education}

The critique lodged against RME is meaningfully analysed and reported on by the editor in chapter 1 . Whether horizontal mathematisation is over-emphasised in the RME context, as opposed to vertical mathematisation as claimed by critics, is debatable. It is understandable that a more balanced approach would be preferred to over-emphasising of applications. I agree that the 'assumed lack of guidance' that RME is accused of is indeed the 'opposite of what RME stands for' (p. 13). The RME principle of guided re-invention is proof that guidance is generally an inherent feature of RME.

The debate that centres on the interpretation (p. 14) of the meaning of 'realistic' in RME terms is interesting. I agree that the 'experiential or emotional worlds' may not always refer to the child's reality. What is crucial is the context used to enhance sense-making, understanding and conceptualisation. Relevant here is the fantasy context used by Freudenthal to explain addition and subtraction of integers that relates to the witch who brews potions, using wonder cubes to regulate the temperature inside the pot she uses (Adendorff, 2012).

\section{The train of thought of the authors}

The train of thought of the contributing authors I find relatively easy to follow. Although the authors are from different backgrounds and experiences, with discernible authentic contexts, the central theme pivotal to RME never fades or gets lost.

The connections, related to RME principles, that tie together the various parts, events and arguments in the different chapters, are foregrounded. So the thread of the central theme, namely the reflective international reflections on RME encounters, is never lost as the reader goes from one chapter to another, and from one country context to another. The RME related contexts used by the authors allow the reader to construct meaning and also direct the reader's attention to a specific train of thought and interpretation (Samson, 2017).

\section{Glossary}

I paged to the back of the book to look for a related term and found that there was no glossary. Readers of this book will naturally come from various backgrounds and will have different levels of expertise. There are numerous RME terms that may not be familiar to educators, thus educators who are new to RME may find a glossary of terms at the end of the book quite useful.

\section{Significance of the book}

This book not only aligns favourably to other books written on RME - such as that of Koeno Gravenmeijer (1994), titled Developing Realistic Mathematics Education, and Marja van den Heuvel-Panhuizen's (ed., 2001) Children learn mathematics: A learning-teaching trajectory with intermediate attainment targets for calculation with whole numbers in primary school - but also gives diverse perspectives on the implementation and use of RME globally.

The intended purpose of the book relates to the reflections of 44 countries outside of the Netherlands on RME, which originated in the Netherlands (p. v).

The significance and influence of this book lie in the powerful testimonies shared by the contributing authors. The contributions of authors from the various countries provide ample evidence of the extent of the impact of RME on different communities worldwide. RME seemed to have served as catalyst for meaningful, deep and wide-reaching change. Sun and He (chapter 10, p. 175) mention the fact that 
'RME exerted an effect on the latest curriculum reform in mathematics education in China in terms of policy-making, new textbook design and change in classroom teaching'. Da Ponte and Brocardo (chapter 12, p. 209) talk of RME as having 'a clear influence in Portugal, in both research and in curriculum development'. Zulkardi, Putri and Wijaja (chapter 18, p. 326) state that 'learning from the successes in the United States and South Africa in reforming mathematics using Realistic Mathematics Education (RME), Indonesia also used and adapted RME to improve mathematics education'.

The intended purpose of the book clearly resides in its title and contributes to the advancement of RME as 'a didactic approach or a domain-specific instruction theory for mathematics' (Zulkardi, Putri \& Wijaja, p. 326). The rigour of the research and scholarship are evident throughout. The narratives and arguments provided are generally sound and relatively easy to follow. As indicated earlier, a comparison with earlier texts on RME places this book in the existing literature. I strongly recommend this book as a valuable resource.

\section{References}

Adendorff, S.A. (2012). A critical analysis of a textbook activity: The teaching and learning of addition and subtraction of integers in the Senior Phase. In S. Nieuwoudt, D. Laubscher, \& H. Dreyer (Eds.), Proceedings of the 18th Annual National Congress of the Association for Mathematics Education of South Africa (Vol. 1, pp. 70-80). Potchefstroom: AMESA. Retrieved from http://www.amesa.org.za/AMESA2012/ Volume1.pdf

Gerson, S., \& Gerson, S. (2006). Technical writing: Process and product. Upper Saddle River, NJ: Pearson Prentice Hall.

Gravemeijer, K. (1994). Developing Realistic Mathematics Education. Utrecht: Freudenthal Institute.

Samson, J. (2017). Why context matters in writing: Building a relationship with the reader. The Writing Cooperative. Retrieved from https://writingcooperative.com/ why-context-matters-in-writing-f52ad075c07a

Sfard, A. (2015). Learning, commognition and mathematics. In D. Scott, \& E. Hargreaves (Eds.), The Sage handbook of learning (pp. 129-138). London: Sage. https://doi. org/10.4135/9781473915213.n12

Skemp, R. (1976). Relational understanding and instrumental understanding. Mathematics Teaching, 77, 20-26.

Van den Heuvel-Panhuizen, M. (Ed.). (2001). Children learn mathematics: A learningteaching trajectory with intermediate attainment targets for calculation with whole numbers in primary school. Utrecht: Freudenthal Institute. 